\title{
KING GEORGE VI
}

Since our last issue the peoples of the Nation and Commonwealth have sustained a grievous loss in the death of His Majesty, King George VI. I saw the sorrow of the Indian Nation when their beloved Ghandiji was taken so suddenly away. I was privileged to be in India at the time of His Majesty's passing, and I can sincerely state that a similar sense of loss passed through the whole Republic of India. The grief expressed on the day of the passing of the King, the attendances at the Memorial Services throughout the land all indicated the deep affection His Majesty had won in the hearts of the Indian people. King George VI, by his understanding, made a significant contribution towards India's emergence as a free and sovereign Republic in the Commonwealth of Nations, and his name throughout that land will ever be beloved.

Both we and the thousands of patients whom we seek to help, share deeply with all his late Majesty's loyal subjects a sense of deep loss on his sudden death. His Majesty, as Patron of B.E.L.R.A., had shown real personal interest in the work of leprosy relief and healing, and had himself sponsored two infected children, both of whom had been discharged free of symptoms.

We, along with all the devoted subjects of Her Majesty who suffer from leprosy, whose cure and relief was one of His Majesty's deepest concerns, would extend to Her Majesty, the Queen, Queen Elizabeth the Queen Mother and all the members of the Royal family, our sympathy and expression of profound grief and loss.

R. G. COCHRANE. 